\title{
Antioxidant and Anti-Inflammatory Activities of Sasa quelpaertensis Leaf Extracts
}

\author{
Se-Jae Kim, Joon-Ho Hwang, Hye-Sun Shin, \\ Mi-Gyeong Jang, Hee-Chul Ko and Seong-Il Kang \\ Department of Biology and Sasa Industry Development Agency, \\ Jeju National University, Jeju, \\ Republic of Korea
}

\section{Introduction}

Oxidative stress plays a critical role in the pathogenesis of inflammation (Winrow et al., 1993), which is a physiological response that protects the body from stimuli including infections and tissue injury. The magnitude of the inflammatory response is crucial, and insufficient responses result in immunodeficiency, which can lead to infection and cancer. Excessive responses cause morbidity and mortality from diseases such as rheumatoid arthritis, Crohn's disease, atherosclerosis, diabetes, Alzheimer's disease, multiple sclerosis, and cerebral and myocardial ischemia (Tracey, 2002). Inflammation is associated with a wide range of inflammatory mediators that initiate inflammatory responses, recruit and activate other cells to the site of inflammation, and subsequently resolve the inflammation (Gallin \& Snyderman, 1999). The expression of pro-inflammatory mediators such as cytokines, chemokines, adhesion molecules, iNOS, and COX-2 involves nuclear factor- $\mathrm{B}$ (NF-kB) (Baeuerle \& Baltimore, 1996; Hayden \& Ghosh, 2004). Mitogen-activated protein kinases (MAPKs) pathways are also reportedly stimulated by inflammatory mediators (Guha \& Mackman, 2001).

The genus Sasa (Poaceae) is composed of perennial plants commonly known as bamboo grasses, and various Sasa species are widely distributed in Asian countries including China, Japan, Korea, and Russia (Okabe et al., 1975). Sasa leaves have been used in traditional medicine for their anti-inflammatory, antipyretic, and diuretic properties (Bae, 2000). Bamboo leaves have also been used in clinical settings to treat hypertension, cardiovascular disease, and cancer (Shibata et al., 1975).

Many recent studies have described the beneficial health effects of Sasa species leaves, which have been used as alternative medicines. S. albomarginata extract reportedly has anticancer properties (Shibata et al., 1979). Both lignin and polysaccharide preparation from Sasa species reportedly have antitumor properties (Suzuki et al., 1968; Yamafuji \& Murakami, 1968). Two polysaccharide preparations (GK1 and GK2) from S. kurilensis was found to negatively affect the growth of Sarcoma-180 implanted in mice (Raidaru et al., 1997). Also, Sasa Health, an alkaline extract derived from $S$. senanensis leaves containing polysaccharides, chlorophyllin, lignin, and flavonoids, reportedly has a protective effect on 
spontaneous mammary tumorigenesis (Tsunoda et al., 1998) and Her2/NeuN mammary tumorigenesis (Ren et al., 2004). Researchers have also recently reported that $S$. senanensis leaf extracts have antioxidant and immunostimulation-mediated antitumor properties (Kurokawa et al., 2006; Seki et al., 2008). Hagasewa et al. (2008) reported antioxidant Cglycosyl flavones in the leaves of S. kurilensis var. gigantea. Extract from S. borealis leaves reportedly improves chronic high glucose-induced endothelial apoptosis (Choi et al., 2008), as well as insulin resistance by modulating inflammatory cytokine secretion in high fat dietinduced obese C57/BL6J mice (Yang et al., 2010). Park et al. (2007) reported four antioxidant flavone glycosides (tricine-7-O- $\beta$-D-glucopyranoside, isoorientin, apigenin 6-C- $\beta$-Dxylopyranosyl-8-C- $\beta$-D-glucopyranoside, isoorientin 2-O-a-L-rhamnoside) from $S$. borealis. Two phenolic compounds, (-)-syringaresinol and tricin, isolated from $S$. borealis, exhibited P-glycoprotein inhibitory properties in adrimiamycin-resistant human breast cancer, MCF7/ARD (Jeong et al., 2007).

S. quelpaertensis Nakai is another bamboo grass. It is a native Korean plant that grows only on Mt. Halla on Jeju Island, South Korea. This small bamboo grass has recently been the focus of much attention due to its potential biomass as well as its role as an invasive plant that inhibits the growth of other plants in the habitat on Jeju Island. Young leaves of $S$. quelpaertensis are used for a popular bamboo tea, but their beneficial health effects and the bioactive compounds contained in the plant have not yet been identified. Thus, systematic research about using its leaves as an industrial bio-resource is increasingly required. As a first step to evaluating the potential of $S$. quelpaertensis leaves as nutraceuticals, in this study, we investigated the anti-oxidative and anti-inflammatory activities of S.quelpaertensis leaf extract.

\section{Materials and methods}

\subsection{Reagents}

Dulbecco's modified Eagle's medium (DMEM), fetal bovine serum (FBS), and penicillinstreptomycin (PS) were obtained from Gibco-BRL (Grand Island, NY, USA). Antibody against inducible NOS (iNOS) was purchased from Calbiochem (San Diego, CA, USA), and antibody against cyclooxygenase-2 (COX-2) was obtained from Becton Dickinson (Mountain View, CA, USA). Anti-phospho-extracellular signal-regulated kinase (ERK1/2) was acquired from Santa Cruz Biotechnology (Santa Cruz, CA, USA). Antibodies against ERK1/2, JNK1/2, phospho-JNK1/2, p38, and phospho-p38 were obtained from Cell Signaling Technology (Beverly, MA, USA). The lactate dehydrogenase (LDH) Cytotoxicity Detection Kit was purchased from Takara Shuzo Co. (Otsu, Shiga, Japan). Protein assay reagent was purchased from Bio-Rad Laboratories Inc. (Hercules, CA, USA). Trizol reagent was purchased from Molecular Research Center Inc. (Cincinnati, OH, USA), lipopolysaccharide (LPS) (Escherichia coli 026:B6) and 3-(4,5-dimethylthiazol-2-yl)-2,5diphenyl tetrazolium bromide (MTT) were purchased from Sigma (St. Louis, MO, USA). All other reagents were acquired from Sigma.

\subsection{Preparation of extracts}

S. quelpaertensis leaves were collected in October 2010, from Mt. Halla on Jeju Island, South Korea. A dried powder of the S. quelpaertensis leaves was extracted using $80 \%$ methanol 
$(\mathrm{MeOH})$ at room temperature for $48 \mathrm{~h}$. This procedure was repeated twice. The combined extract was concentrated on a rotary evaporator under reduced pressure and freeze-dried to a powder. The dried extract was dissolved in water and then fractionated using the organic solvents $n$-hexane (hexane), ethyl acetate (EtOAc), and $n$-butanol (BuOH) at room temperature. Each fraction was concentrated on a rotary evaporator under reduced pressure and freeze-dried to a powder.

\subsection{Measurement of antioxidant activities}

\subsubsection{DPPH radical scavenging assay}

2,2-Diphenyl-1-picrylhydrazyl (DPPH) radical scavenging activity was examined according to the method reported by Tateyama et al. (1997) with slight modifications. Briefly, the extracts were mixed with methanol and then added to $0.4 \mathrm{mM}$ DPPH in methanol. After 20 min of incubation in the dark at room temperature, the reduction in the DPPH free radical was measured by absorbance, which was read using a microplate reader (Bio-Tek Instruments, Winooski, VT, USA) at $517 \mathrm{~nm}$. Trolox and BHA, a stable antioxidant, were used as a reference control and pure methanol was used as a control sample. Three replicates were made for each test sample. The radical scavenging activity of samples, expressed as percent inhibition, was calculated according to the follow formula: \% inhibition $=(A 0 / A X) / A 0 \times 100$, where $A 0$ and $A X$ are the absorbance values of the blank sample and the tested samples, respectively. The results were indicated as $\mathrm{IC}_{50}$, which is the $50 \%$ inhibitory concentration of DPPH radical scavenging activity.

\subsubsection{NO scavenging activity}

Nitric oxide (NO) scavenging activity was measured using the method described by Feelisch and Stamler (1996) with slight modifications. Sodium nitroprusside (SNP) in an aqueous solution at physiological $\mathrm{pH}$ spontaneously generates nitric oxide, which can be measured using the Griess reagent system. The reaction solution containing $1 \mathrm{mM}$ SNP in phosphatebuffered saline (PBS) ( $\mathrm{pH}$ 7.4) was mixed with the extract, followed by incubation at room temperature for $3 \mathrm{~h}$. Then, the reaction solution was mixed with an equal volume of Griess reagent ( $1 \%$ sulfanilamide and $0.1 \%$ naphthylethylenediamine in $5 \%$ phosphoric acid). The absorbance at $540 \mathrm{~nm}$ was recorded using a microplate reader. The percentage of $\mathrm{NO}$ scavenging was measured through comparison with the absorbance values of the blank sample.

\subsubsection{Superoxide radical scavenging assay}

Superoxide $\left(\mathrm{O}_{2}^{-}\right)$was generated using the enzymatic method. Briefly, the extracts were mixed with an equal volume of reaction reagent $\left[2 \mathrm{mM} \mathrm{Na}_{2}\right.$ EDTA in phosphate buffer (50 $\left.\mathrm{mM} \mathrm{KH} \mathrm{PO}_{4} / \mathrm{KOH}, \mathrm{pH} 7.4\right), 0.05 \mathrm{mM}$ nitroblue tetrazolium chloride (NBT) in a buffer, and $1 \mathrm{mM}$ hypoxanthine in $50 \mathrm{mM} \mathrm{KOH}$. The reaction was started by adding xanthine oxidase $(\mathrm{XOD}$ ) in a buffer to the mixture (final XOD concentration was $0.05 \mathrm{U} / \mathrm{ml}$ ). After $1 \mathrm{~h}$ of incubation at room temperature, scavenging activity was measured by absorbance, which was read using a microplate reader at $560 \mathrm{~nm}$. Trolox and BHA, a stable antioxidant, were used as a reference control; SOD and allopurinol were used as a positive control. The NBT reduction (\%) was calculated according to the following formula: $\%$ inhibition = 
$(A 0 / A X) / A 0 \times 100$, where $A 0$ and $A X$ are the absorbance values of the blank sample and the tested samples, respectively.

\subsubsection{Determination of XOD-inhibitory activity}

XOD-inhibitory activity was measured by detecting uric acid formation according to the method described by Puig et al. (1989) with slight modifications. First, the extracts and reaction reagent $2 \mathrm{mM} \mathrm{Na} 2$ EDTA in a phosphate buffer $\left(50 \mathrm{mM} \mathrm{KH}_{2} \mathrm{PO}_{4} / \mathrm{KOH}, \mathrm{pH} 7.4\right)$ and $1 \mathrm{mM}$ hypoxanthine in $50 \mathrm{mM} \mathrm{KOH}$ ] were mixed in a 96-well microplate. The reaction was started by adding XOD in a buffer to the mixture (final XOD concentration was 0.05 $\mathrm{U} / \mathrm{ml}$ ). After $1 \mathrm{~h}$ of incubation at room temperature, uric acid production was measured by absorbance, which was read using a microplate reader at $295 \mathrm{~nm}$. Trolox and BHA, a stable antioxidant, were used as a reference control. SOD and allopurinol were used as a positive control. Uric acid production was calculated according to the following formula: \% inhibition $=(A 0 / A X) / A 0 \times 100$, where $A 0$ and $A X$ are the absorbance values of the blank sample and the tested samples, respectively.

\subsection{Cell culture}

The RAW 264.7 murine macrophage cell line was obtained from the Korea Cell Line Bank (Seoul, Korea). Cells were cultured in 1\% PS/DMEM containing 10\% heat-inactivated FBS at $37^{\circ} \mathrm{C}$ in a $5 \% \mathrm{CO}_{2}$ incubator.

\subsection{Cytotoxicity assay - MTT and LDH release assays}

Cell viability and cytotoxicity were determined using a 3-(4,5-dimethylthiazol-2-yl)-2,5diphenyltetrazolium bromide (MTT) cell viability assay and lactic dehydrogenase (LDH) release assay. Cells were seeded at a density of $5 \times 10^{4}$ cells/well into a 96-well flat-bottom cell culture plate in the presence or absence of the extracts. Mitochondrial enzyme activity, which is an indirect measure of the number of viable respiring cells, was determined using an MTT reagent after $40 \mathrm{~h}$ of treatment with methanol extract or its fractions. Absorbance was read using a microplate reader (Bio-Tek Instruments) at $595 \mathrm{~nm}$. The effect of extracts on cell viability was evaluated as the relative absorbance compared to that of control cultures. LDH leakage is known to be a marker of damage to the cell membrane, and the LDH level was detected using the culture supernatants according to the LDH cytotoxicity detection kit instructions (Takara Shuzo Co.). Cytotoxicity was expressed as the percentage of released $\mathrm{LDH}(\mathrm{LDH}$ released into the medium/maximal $\mathrm{LDH}$ release $\times 100$ ). Maximal LDH release was measured after lysis of the cells with $0.5 \%$ Triton X-100.

\subsection{Measurement of $\mathrm{NO}$ and $\mathrm{PGE}_{2}$ production}

The amount of nitrite was determined using a colorimetric assay (Green et al., 1982). Briefly, $100 \mu \mathrm{l}$ of cell culture medium was mixed with an equal volume of Griess reagent $(1 \%$ sulfanilamide and $0.1 \%$ naphthylethylenediamine in 5\% phosphoric acid) and incubated at room temperature for $10 \mathrm{~min}$. The absorbance at $540 \mathrm{~nm}$ was recorded using a microplate reader. Nitrite concentration was determined using extrapolation from a sodium nitrite standard curve. Concentration of prostaglandin $\mathrm{E}_{2}\left(\mathrm{PGE}_{2}\right)$ in the culture medium was 
quantified by enzyme-linked immunosorbent assay (ELISA) according to the manufacturer's instructions.

\subsection{Measurement of iNOS enzyme activity}

The activity of the iNOS enzyme in the cell lysate was measured as the L-arginine- and NADPH-dependent generation of nitrite. Briefly, $200 \mu \mathrm{g}$ cell lysate was incubated for 180 min at room temperature in $100 \mu \mathrm{l}$ of a reaction buffer containing $20 \mathrm{mM}$ sodium phosphate buffer, $2 \mathrm{mM}$ NADPH, $2 \mathrm{mM}$ L-arginine, and $10 \mu \mathrm{m}$ FAD at $\mathrm{pH}$ 6.7. The reaction was stopped by adding $10 \mathrm{U} / \mathrm{ml} \mathrm{LDH}$ and $10 \mathrm{mM}$ pyruvate. Next, the reaction mixture was incubated with an equal volume of Griess reagent. The absorbance at $540 \mathrm{~nm}$ was recorded using a microplate reader. Nitrite concentration was determined by extrapolation from a sodium nitrite standard curve.

\subsection{Western blot analysis}

Cells were washed twice with ice-cold PBS and collected. The cells were then treated with a lysis buffer [1× RIPA (Upstate Cell Signaling Solutions, Lake Placid, NY, USA), $1 \mathrm{mM}$ phenylmethylsulfonyl fluoride (PMSF), $1 \mathrm{mM} \mathrm{Na} \mathrm{VO}_{4}, 1 \mathrm{mM} \mathrm{NaF}, 1 \mu \mathrm{g} / \mathrm{ml}$ aprotinin, 1 $\mu \mathrm{g} / \mathrm{ml}$ pepstatin, and $1 \mu \mathrm{g} / \mathrm{ml}$ leupeptin] and incubated on ice for $1 \mathrm{~h}$. Cell debris was removed by centrifugation and then protein concentration was determined using a Bio-Rad protein assay reagent (Bio-Rad Laboratories, Hercules, CA, USA). Cell lysates were subjected to $7.5 \%$ or $10 \%$ SDS-polyacrylamide gel electrophoresis and transferred to polyvinylidene difluoride membranes. The membranes were blocked with a solution of $0.1 \%$ Tween 20/Tris-buffed saline containing 5\% nonfat milk powder for $1 \mathrm{~h}$ at room temperature. After incubation overnight at $4^{\circ} \mathrm{C}$ with the indicated primary antibody, the membranes were incubated with a horseradish peroxidase-conjugated secondary antibody for $1 \mathrm{~h}$ at room temperature. Immunodetection was carried out using an ECL Western blotting detection reagent. The signal intensity of relative bands was determined using image acquisition and analysis software (LabWorks, Cambridge, UK).

\subsection{RNA preparation and reverse transcription-polymerase chain reaction (RT-PCR)}

Total cellular RNA was isolated using a Trizol reagent (Molecular Research Center, Cincinnati, OH, USA) according to the manufacturer's instructions. RNA concentration and purity were determined by measuring absorbance at 260 and $280 \mathrm{~nm}$. A cDNA synthesis was performed using the ImProm-II ${ }^{\mathrm{TM}}$ Reverse Transcription System (Promega, Madison, WI, USA) with an oligo dT-15 primer, as recommended by the supplier. PCR analyses were then performed on aliquots of cDNA preparations using a thermal cycler. The reactions were carried out in a $25 \mu \mathrm{l}$ volume containing (final concentration) 1 unit of Taq DNA polymerase, $0.2 \mathrm{mM} \mathrm{dNTP}, 10 \times$ reaction buffer, and 100 pmol primers (Table 1 ). The cycle number was optimized to ensure product accumulation in the exponential range. $\beta$-Actin was used as an internal control to normalize the RNA content of each sample. Amplification was initiated at $94^{\circ} \mathrm{C}$ for $5 \mathrm{~min}$, followed by $18-27$ cycles of denaturation at $94^{\circ} \mathrm{C}$ for $45 \mathrm{~s}$, annealing at the appropriate primer-pair annealing temperature for $45 \mathrm{~s}$, and extension at $72^{\circ} \mathrm{C}$ for $1 \mathrm{~min}$, followed by a final extension of $10 \mathrm{~min}$ at $72^{\circ} \mathrm{C}$. After amplification, portions of the PCR reactions were electrophoresed on $2 \%$ agarose gel and visualized using ethidium 
bromide staining and a UV transilluminator (SLB Mylmagger; UVP Inc., Upland, CA, USA). The signal intensity of relative bands was determined using image acquisition and analysis software (LabWorks).

\begin{tabular}{ccc}
\hline Gene & & Primer sequences \\
\hline \multirow{2}{*}{ iNOS } & Forward & $5^{\prime}$-CCCTTCCGAAGTTTCTGGCAGCAGC-3' \\
& Reverse & $5^{\prime}$-GGCTGTCAGAGCCTCGTGGCTTTGG-3' \\
COX-2 & Forward & $5^{\prime}$-CACTACATCCTGACCCACTT-3' \\
& Reverse & $5^{\prime}$-ATGCTCCTGCTTGAGTATGT-3' \\
TNF- $\alpha$ & Forward & $5^{\prime}$-TTGACCTCAGCGCTGAGTTG-3' \\
& Reverse & $5^{\prime}$-CCTGTAGCCCACGTCGTAGC-3' \\
IL-1 $\beta$ & Forward & $5^{\prime}$-CAGGATGAGGACATGAGCACC-3' \\
& Reverse & $5^{\prime}$-CTCTGCAGACTCAAACTCCAC-3' \\
IL-6 & Forward & $5^{\prime}$-GTACTCCAGAAGACCAGAGG-3' \\
& Reverse & $5^{\prime}$-TGCTGGTGACAACCACGGCC-3' \\
\multirow{2}{*}{$\beta$-Actin } & Forward & $5^{\prime}$-AGGCTGTGCTGTCCCTGTATGC-3' \\
& Reverse & $5^{\prime}$-ACCCAAGAAGGAAGGCTGGAAA-3 \\
\hline
\end{tabular}

Table 1 . The sequences of primers used in RT-PCR analysis.

\subsection{Transient transfection and luciferase assay}

Cells were seeded at a density of $5 \times 10^{3}$ cells/well into a 96-well flat-bottom cell culture plate and cultured for $18 \mathrm{~h}$. RAW 264.7 cells were transiently transfected with or without a

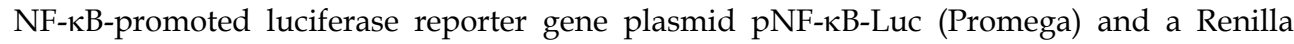
luciferase reporter plasmid pRL-TK (Stratagene, La Jolla, CA, USA), to control for transfection efficiency using a FuGENE 6 transfection reagent (Roche, Indianapolis, IN, USA). At $24 \mathrm{~h}$ after the start of transfection, cells were incubated with LPS (100 ng/ml) in the presence or absence of the extracts for $24 \mathrm{~h}$. Luciferase activity in the cell lysate was measured using a Dual-Luciferase Reporter Assay Kit (Promega) and a FLUOstar Optima (BMG Labtech, Offenburg, Germany). Luciferase activity was normalized to transfection efficiency, as monitored using a Renilla luciferase expression vector. The level of induced luciferase activity was determined as a ratio to the luciferase activity of unstimulated cells.

\subsection{Statistical analysis}

All experiments were conducted in triplicate, but only data from one representative trial are presented. Results are expressed as the mean \pm standard deviation (SD). Treatment effects were analyzed using a paired $t$-test.

\section{Results}

\subsection{Antioxidant activities of S. quelpaertensis leaf extracts}

Table 2 summarizes the antioxidant activities of $S$. quelpaertensis leaf methanol extract and its fractions, represented by $\mathrm{IC}_{50}$. The $\mathrm{IC}_{50}$ values for $\mathrm{DPPH}$ radical scavenging activity against $\mathrm{MeOH}$ extract, EtOAc, and $\mathrm{BuOH}$ fractions were 862.5, 288.9, and $166.4 \mu \mathrm{g} / \mathrm{ml}$, respectively. 
DPPH radical scavenging activity of the $\mathrm{BuOH}$ fraction was more potent than that of other tested samples. For $\mathrm{NO}$ scavenging activity, the $\mathrm{IC}_{50}$ value $(259.4 \mu \mathrm{g} / \mathrm{ml})$ was calculated only for the EtOAc fraction; other tested samples exhibited minimal NO scavenging activity. All tested samples (except the water fraction) exhibited XOD-inhibition activity and superoxide radical scavenging activity. XOD-inhibition activity occurred in the following (decreasing) order: EtOAc fraction $>$ hexane fraction $>\mathrm{MeOH}$ extract $>\mathrm{BuOH}$ fraction. Superoxide radical scavenging activity occurred in the following (decreasing) order: EtOAc fraction $>\mathrm{BuOH}$ fraction $>$ hexane fraction $>\mathrm{MeOH}$ extract $>$ water fraction. The $\mathrm{IC}_{50}$ values for the EtOAc fraction on XOD-inhibition activity and superoxide radical scavenging activity assay were 32.4 and $21.9 \mu \mathrm{g} / \mathrm{ml}$, respectively. As shown in Table 2, overall antioxidant activity was more potent in the EtOAc fraction than in any other tested samples.

\begin{tabular}{ccccc}
\hline \multirow{2}{*}{ Sample } & \multicolumn{4}{c}{$\mathrm{IC}_{50}(\mu \mathrm{g} / \mathrm{ml})$ a) } \\
\cline { 2 - 5 } & $\begin{array}{c}\text { DPPH radical } \\
\text { scavenging } \\
\text { activity }\end{array}$ & $\begin{array}{c}\text { Nitric oxide } \\
\text { scavenging } \\
\text { activity }\end{array}$ & $\begin{array}{c}\text { Uric acid } \\
\text { generation } \\
\text { activity }\end{array}$ & $\begin{array}{c}\text { Superoxide } \\
\text { generation } \\
\text { activity }\end{array}$ \\
\hline Methanol extract & $862.5 \pm 6.4$ & $*$ & $352.9 \pm 16.0$ & $113.5 \pm 13.4$ \\
Hexane fraction & $*$ & $*$ & $238.4 \pm 5.6$ & $62.8 \pm 4.3$ \\
EtOAc fraction & $288.9 \pm 12.7$ & $259.4 \pm 1.6$ & $32.4 \pm 1.6$ & $21.9 \pm 5.4$ \\
BuOH fraction & $166.4 \pm 9.4$ & $*$ & $473.5 \pm 15.4$ & $23.4 \pm 5.9$ \\
Water fraction & $*$ & $*$ & - & $305.2 \pm 6.9$ \\
Trolox & $3.49 \pm 0.3$ & $*$ & $220.3 \pm 12.3$ & $32.5 \pm 1.9$ \\
BHA b) & $7.6 \pm 0.2$ & $*$ & $801.7 \pm 11.7$ & $*$ \\
Allopurinol & $\mathrm{N} / \mathrm{A}$ & $\mathrm{N} / \mathrm{A}$ & $1.33 \pm 0.1$ & $5.1 \pm 0.1$ \\
SOD c) & $\mathrm{N} / \mathrm{A}$ & $\mathrm{N} / \mathrm{A}$ & $*$ & $4.9 \pm 1.9$ \\
\hline
\end{tabular}

a) IC50 values were calculated from regression lines using five different concentrations in triplicate experiments.

b) Butylated hydroxyl anisole

c) Superoxide dismutase

N/A: Not assay

*: Can't calculate the value of IC50

$-:<5 \%$ xanthine oxidase inhibitory activity at maximum concentration used for assay.

Table 2. Antioxidant activities of the methanol extract and its various fractions from Sasa quelplaertensis leaf.

\begin{tabular}{cccc}
\hline Sample & $\mathrm{TC}_{50^{\mathrm{a}}}(\mu \mathrm{g} / \mathrm{ml})$ & $\left.\mathrm{IC}_{50} \mathrm{~b}\right)(\mu \mathrm{g} / \mathrm{ml})$ & Selectivity index $)$ \\
\hline MeOH extract & $>2000$ & $1341.7 \pm 4.9$ & $>1.8$ \\
Hexane fraction & $240.1 \pm 19.8$ & $175.0 \pm 9.6$ & 1.4 \\
EtOAc fraction & $465.2 \pm 10.2$ & $68.6 \pm 0.1$ & 6.8 \\
BuOH fraction & $>2000$ & $>2000$ & - \\
Water fraction & $>2000$ & $>2000$ & - \\
\hline
\end{tabular}

a) $\mathrm{TC}_{50}$ is the concentration producing $50 \%$ toxicity in RAW 264.7 cells.

b) $\mathrm{IC}_{50}$ is the concentration producing $50 \%$ inhibition of NO production in RAW 264.7 cells.

c) Selectivity Index $=\mathrm{TC}_{50} / \mathrm{IC}_{50}$.

Table 3. Cell toxicity and the effects of the methanol extract and its fractions of Sasa quelpaetensis on LPS-induced NO production in RAW 264.7 cells. 
Next, we compared the effects of $S$. quelpaertensis leaf extract on LPS-induced NO production in RAW 264.7 cells (see Table 3). Among the tested samples, the EtOAc fraction had the highest selectivity index (6.8), indicating it had potent anti-inflammatory properties. Thus, we focused on the anti-inflammatory effects of the EtOAc fraction using LPSstimulated RAW 264.7 cells.

\subsection{EtOAc fraction inhibits NO production and iNOS expression}

The effects of the EtOAc fraction on NO production in LPS-stimulated RAW 264.7 cells were investigated by measuring the amount of nitrite released into the culture medium using a

A

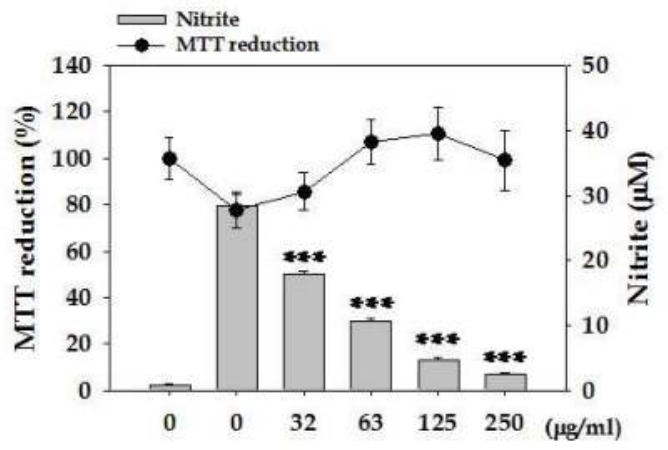

B

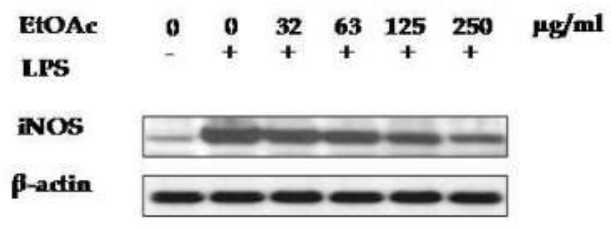

C

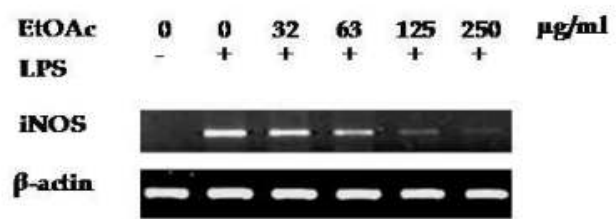

Fig. 1. Effect of EtOAc fraction on the NO production, iNOS protein and iNOS mRNA expression level in LPS-stimulated RAW 264.7 cells. (A) Cells were treated with LPS (100 $\mathrm{ng} / \mathrm{ml}$ ) alone or LPS plus the indicated concentrations of EtOAc fraction for $24 \mathrm{~h}$. ${ }^{* * *} P<$ 0.001 vs LPS alone-treated cells. Data are expressed in area density as the mean \pm SD for three independent experiments. (B) Cells were treated with LPS (100 ng/ml) alone or LPS plus the indicated concentrations $(\mu \mathrm{g} / \mathrm{ml})$ of EtOAc fraction for $24 \mathrm{~h}$. (C) Cells were cotreated with LPS $(100 \mathrm{ng} / \mathrm{ml})$ or LPS with EtOAc fraction at the indicated concentration for 6h. Total RNA was subjected to RT-PCR. 
Griess reagent system. As shown in Fig. 1A, NO levels increased remarkably with LPS, up to $30 \mu \mathrm{M}$, but co-treatment with the EtOAc fraction significantly decreased NO levels in a dose-dependent manner. In addition, the EtOAc fraction did not affect the viability of RAW 264.7 cells at concentrations from 32 to $250 \mu \mathrm{g} / \mathrm{ml}$.

To investigate whether the inhibition of NO production by the EtOAc fraction was a result of inhibition of the corresponding gene expression, we analyzed the expression of iNOS protein and mRNA using Western blotting and RT-PCR. LPS increased the levels of cellular iNOS protein and mRNA at $24 \mathrm{~h}$ and $6 \mathrm{~h}$ after treatment, respectively. However, cotreatment of the EtOAc fraction $(32,63,125$ and $250 \mu \mathrm{g} / \mathrm{ml})$ with LPS decreased both LPSinduced protein (Fig. 1B) and iNOS mRNA (Fig. 1C) in a dose-dependent manner.

We also measured iNOS enzymic activity to investigate whether the EtOAc fraction affected enzymatic activity. As shown in Fig. 2, EtOAc treatment $(32,63,125$ and $250 \mu \mathrm{g} / \mathrm{ml})$ did not affect iNOS protein enzyme activity. However, iNOS enzyme activity was inhibited by 1400 $\mathrm{W}$, which was used as the positive control (data not shown). These results confirmed that the EtOAc fraction inhibited NO production in LPS-stimulated RAW 264.7 cells through the regulation of iNOS gene expression.

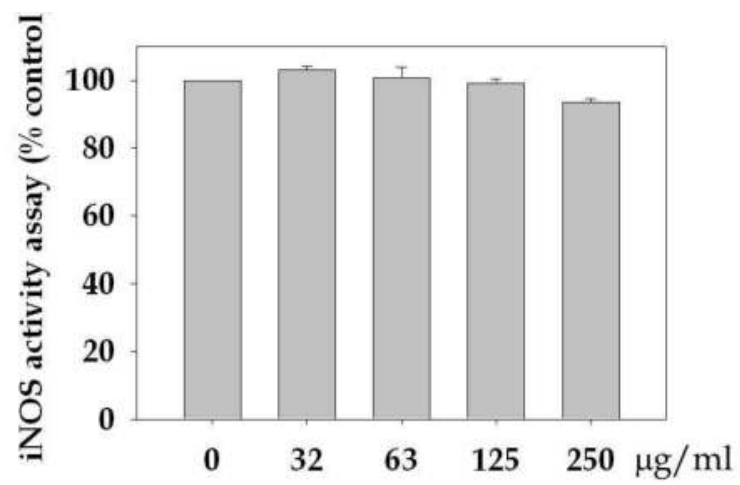

Fig. 2. Effect of EtOAc fraction on iNOS enzyme activity. The iNOS activity was measured as using L-arginine as substrate and NADPH-dependent generation of nitrite, the stable oxidation products of NO. The assay was performed by incubating with $200 \mu \mathrm{g}$ of the cytosol protein from LPS-stimulated cells, in the absence or presence of EtOAc fraction, for $180 \mathrm{~min}$ at room temperature in $200 \mu \mathrm{l}$ reaction buffer containing $20 \mathrm{mM}$ Tris- $\mathrm{HCl}, \mathrm{pH}$ 8.0, $2 \mathrm{~mm}$ NADPH, $2 \mathrm{~mm}$ L-arginine, $10 \mu \mathrm{M}$ FAD. $\mathrm{NO}_{3}$ - was reduced to $\mathrm{NO}_{2}$ - by incubation at $37^{\circ} \mathrm{C}$ for $15 \mathrm{~min}$ with $0.1 \mathrm{U} / \mathrm{ml}$ nitrate reductase, $0.1 \mathrm{mM}$ NADPH, $5 \mu \mathrm{M}$ FAD.

\subsection{EtOAc fraction inhibits $\mathrm{PGE}_{2}$ production and COX-2 expression}

$\mathrm{PGE}_{2}$ is the major metabolite produced by COX-2 at inflammation sites. Therefore, we examined the effects of the EtOAc fraction on $\mathrm{PGE}_{2}$ production and COX-2 expression. $\mathrm{PGE}_{2}$ production increased remarkably with LPS $(7,800 \mathrm{pg} / \mathrm{ml})$, but co-treatment with the EtOAc fraction significantly decreased $\mathrm{PGE}_{2}$ production in a dose-dependent manner (Fig. 3A).

To investigate whether the inhibition of $\mathrm{PGE}_{2}$ production by the EtOAc fraction was due to inhibition of the corresponding gene expression, we analyzed the expression of COX-2 
protein and mRNA using Western blotting and RT-PCR. As shown in Fig. 3B, COX-2 protein levels increased in response to LPS treatment, but co-treatment of the EtOAc fraction $(32,63,125$ and $250 \mu \mathrm{g} / \mathrm{ml})$ with LPS decreased COX-2 protein levels in a dose-dependent manner. In addition, RT-PCR analysis revealed that the expression of COX-2 mRNA was correlated with its protein levels (Fig. 3C). These results indicate that the inhibitory effect of the EtOAc fraction on $\mathrm{PGE}_{2}$ production involved regulation of $\mathrm{COX}-2$ gene expression.

A

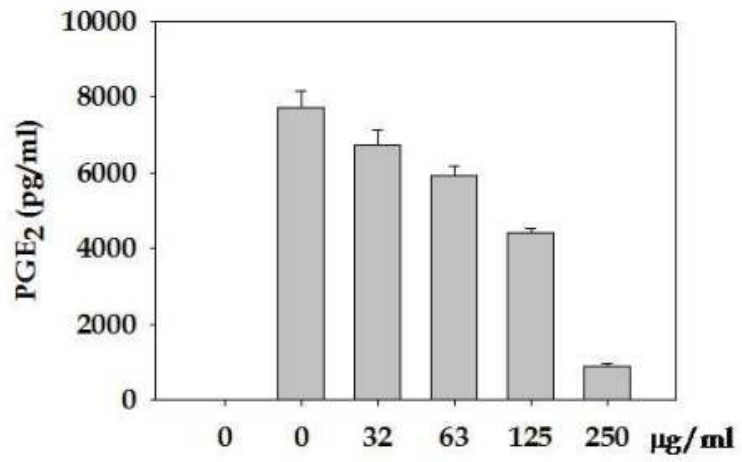

B

$\begin{array}{lccccccc}\text { EtOAC } & 0 & 0 & 32 & 63 & 125 & 250 & \mu \mathrm{g} / \mathrm{ml}\end{array}$

COX-2

Bractin
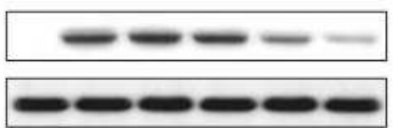

C

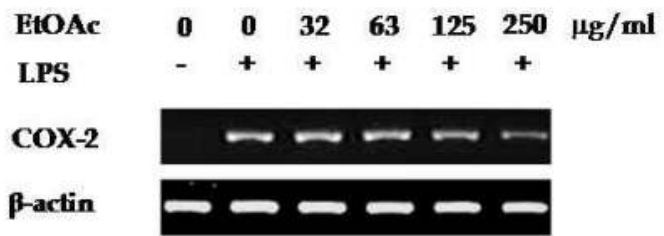

Fig. 3. Effect of EtOAc fraction on the $\mathrm{PGE}_{2}$ production, COX-2 protein and mRNA expression level in LPS-stimulated RAW 264.7 cells. (A) Cells were treated with LPS (100 $\mathrm{ng} / \mathrm{ml}$ ) alone or LPS plus the indicated concentrations of EtOAc fraction for $24 \mathrm{~h}$. ${ }^{* * *} P<$ 0.001 vs LPS alone-treated cells. Data are expressed in area density as the mean \pm SD for three independent experiments. (B) Cells were treated with LPS (100 ng/ml) alone or LPS plus the indicated concentrations $(\mu \mathrm{g} / \mathrm{ml})$ of EtOAc fraction for $24 \mathrm{~h}$. (C) Cells were cotreated with LPS $(100 \mathrm{ng} / \mathrm{ml})$ or LPS with EtOAc fraction at the indicated concentration for 6 h. Total RNA was subjected to RT-PCR. 


\subsection{EtOAc fraction inhibits pro-inflammatory cytokine mRNA expression}

Pro-inflammatory cytokines, such as IL-1 $\beta$, IL-6, and TNF- $\alpha$, are known to affect LPSinduced macrophage activation during immune responses. Therefore, we investigated the effects of the EtOAc fraction on the expression of TNF- $\alpha$, IL-1 $\beta$, and IL- 6 mRNA in LPSstimulated RAW 264.7 cells using RT-PCR analysis. The mRNA levels of these cytokines increased at $6 \mathrm{~h}$ (IL-1 $\beta$ and IL-6) or $4 \mathrm{~h}$ (TNF- $\alpha$ ) after LPS treatment. However, co-treatment with the indicated concentrations of EtOAc fraction significantly decreased LPS-induced TNF- $\alpha$, IL-1 $\beta$, and IL-6 mRNA levels in a dose-dependent manner (Fig. 4); at a EtOAc fraction concentration of $125 \mu \mathrm{g} / \mathrm{ml}$, mRNA levels of IL-1 $\beta$, IL-6, and TNF- $\alpha$ decreased by $55 \%, 60 \%$, and $45 \%$, respectively (Fig. $4 \mathrm{~B}$ ).

A

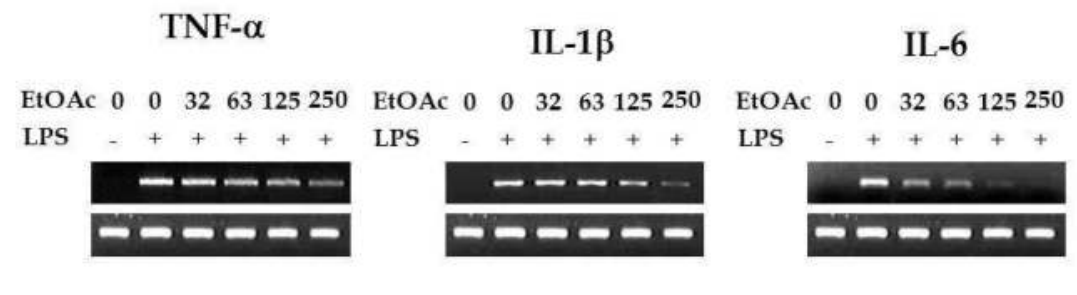

B
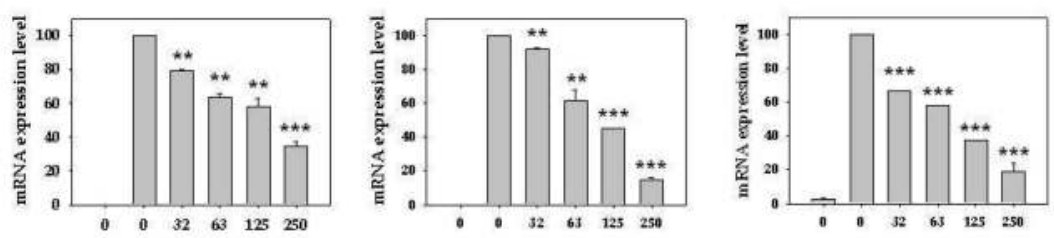

Fig. 4. Effect of EtOAc fraction on TNF- $\alpha$, IL-1 $\beta$ and IL-6 mRNAs expression level in LPSstimulated RAW 264.7 cells. (A) RT-PCR analysis of TNF- $\alpha$, IL-1 $\beta$ and IL-6 mRNA expression using total RNA extracted RAW 264.7 macrophages stimulated with LPS (100 $\mathrm{ng} / \mathrm{ml})$ alone or LPS plus the indicated concentrations $(\mu \mathrm{g} / \mathrm{ml})$ of EtOAc fraction for $6 \mathrm{~h}$ (TNF- $\alpha$ for $4 \mathrm{~h}$ ). (B) Quantification of TNF- $\alpha$, IL-1 $\beta$, and IL-6 mRNA expression was performed by densitometric analysis of the RT-PCR products. The relative level was calculated as the ratio of pro-inflammatory mRNA expression to $\beta$-actin mRNA expression. ${ }^{* * *} P<0.001,{ }^{* *} P<0.01$ vs LPS alone-treated cells.

\subsection{EtOAc fraction suppresses NF-KB transcriptional activation}

NF-KB regulated the expression of pro-inflammatory cytokines, iNOS, and COX-2. Therefore, we investigated the effect of the EtOAc fraction on NF- $\mathrm{BB}$ activation using a transient transfection assay with a NF- $\mathrm{BB}$-promoted luciferase reporter gene plasmid (pNF$\kappa B-L u c)$ in RAW 264.7 cells. The treatment group of EtOAc fraction alone exhibited activity similar to the unstimulated control group, confirming that the EtOAc fraction had no effect 
on NF- $\mathrm{kB}$ activation in the cells. However, LPS treatment (100 ng/ml, $24 \mathrm{~h})$ increased luciferase activity 12-fold compared to the unstimulated control group. The EtOAc fraction significantly decreased LPS-induced luciferase activity in a dose-dependent manner (Fig. 5). At a concentration of $125 \mu \mathrm{g} / \mathrm{ml}$, the EtOAc fraction decreased luciferase activity by approximately $70 \%$ compared to the LPS-stimulated control group. This finding suggests that the EtOAc fraction exerts anti-inflammatory effects by suppressing the NF- $\mathrm{kB}$ activation pathway.

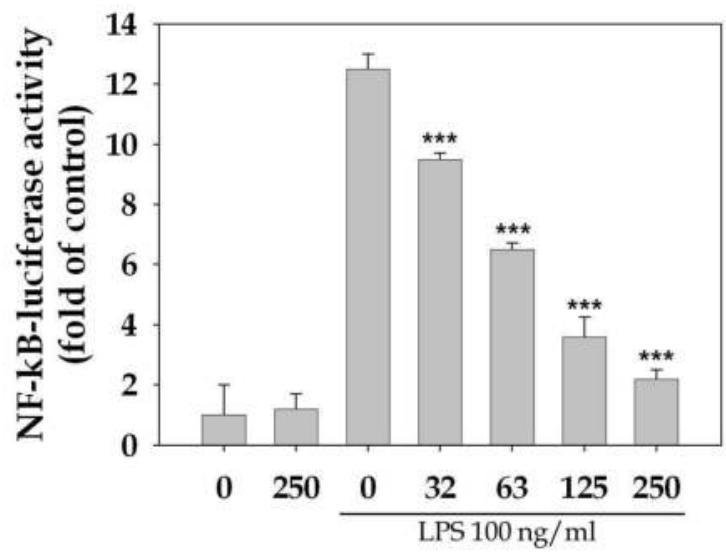

Fig. 5. Effect of EtOAc fraction on LPS-induced NF-kB transcriptional activation. Cells were treated with LPS $(100 \mathrm{ng} / \mathrm{ml})$ alone or LPS plus the indicated concentrations $(\mu \mathrm{g} / \mathrm{ml})$ of EtOAc fraction for $24 \mathrm{~h}$. NF- $\mathrm{kB}$ activation detected by luciferase reporter assays. *** $P<0.001$ vs LPS alone-treated cells.

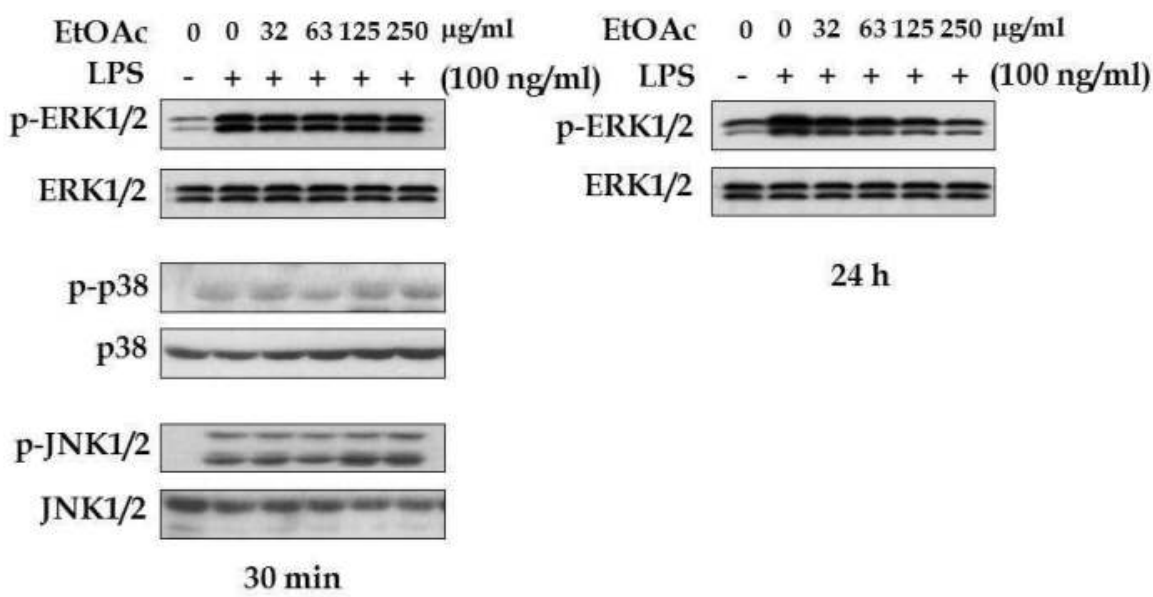

Fig. 6. Effect of EtOAc fraction on the phosphorylation of ERK1/2, p38, and JNK in LPSstimulated RAW 264.7 cells. Cells were treated with LPS $(100 \mathrm{ng} / \mathrm{ml})$ alone or LPS plus the indicated concentrations $(\mu \mathrm{g} / \mathrm{ml})$ of EtOAc fraction for $30 \mathrm{~min}$ or $24 \mathrm{~h}$. The protein levels were determined by Western blotting. 


\subsection{EtOAc fraction suppresses the phosphorylation of ERK1/2}

Because some MAPKs are known to be stimulated by inflammatory mediators, we also investigated how the EtOAc fraction affected three MAPKs (ERK1/2, JNK1/2, and p38 MAPK) in LPS-stimulated RAW 264.7 macrophages. The phosphorylations of these three kinases were detected after cells were subjected to $30 \mathrm{~min}$ of LPS treatment. The activation of the three MAPKs by LPS treatment did not decrease with co-treatment of the EtOAc fraction, but the EtOAc fraction suppressed the phosphorylation of ERK1/2 at $24 \mathrm{~h}$ after LPS treatment (Fig. 6).

\section{Discussion}

In the human body, oxidative stress is associated with many diseases. Therefore, researchers are currently intensely focused on identifying antioxidant agents in plants that may protect against oxidative stress, including the Sasa species already used in alternative medicines (Jensen et al., 2008; Nakajima et al., 2003; Sood et al., 2009). This study evaluated the potential of using S. quelpaertensis leaf in nutraceuticals. As the first step toward identifying phytochemicals with beneficial health effects from $S$. quelpaertensis leaf extracts, we evaluated in vitro antioxidant capacities such as DPPH radical scavenging activity, NO scavenging activity, XOD-inhibitory activity, and superoxide radical scavenging activity.

Among the various fractions, the $n$-butanol soluble fraction exhibited the strongest DPPH radical scavenging activity $\left(\mathrm{IC}_{50}=166.4 \mu \mathrm{g} / \mathrm{ml}\right)$. This result was consistent with the results of Park et al. (2007), who also found significant DPPH radical scavenging activity in the nbutanol soluble fraction among $n$-hexane, EtOAc, and aqueous extracts from $S$. borealis. However, the EtOAc fraction was the most potent in nitric oxide scavenging activity $\left(\mathrm{IC}_{50}=\right.$ $259.4 \mu \mathrm{g} / \mathrm{ml}$ ), superoxide scavenging activity $\left(\mathrm{IC}_{50}=21.9 \mu \mathrm{g} / \mathrm{ml}\right)$, and xanthine oxidase inhibitory activity $\left(\mathrm{IC}_{50}=32.4 \mu \mathrm{g} / \mathrm{ml}\right)$, suggesting its potential as an antioxidant agent.

Antioxidants such as vitamins $\mathrm{C}$ reportedly exhibit anti-inflammatory activity via suppression of NF-KB activation (Calfee-Mason et al., 2002; Muñoz et al., 1997). Therefore, we further investigated the anti-inflammatory potential of the EtOAc fraction, which exhibited the strongest antioxidant potential among various solvent fractions using the RAW 264.7 cell line.

$\mathrm{NO}$ is an essential bio-regulatory molecule within the nervous, immune, and cardiovascular systems (Bredt \& Snyder, 1990; Gold et al., 1990; Palmer et al., 1987). However, increased levels of NO derived from iNOS can result in the formation of peroxynitrite after reaction with oxygen free radicals during inflammatory responses (Posadas et al., 2000). In the RAW 264.7 cell, NO production is closely associated with COX-2 expression (Salveminiet al., 1995), which produces $\mathrm{PGE}_{2}$ and induces an inflammatory reaction (Bennett et al., 1977a, 1980b, 1982c; Rigas et al., 1993). iNOS and COX-2 are key enzymes regulating the production of $\mathrm{NO}$ and $\mathrm{PGE}_{2}$, central mediators of inflammation (Possadas et al., 2000; Tsatsanis et al., 2006).

This study demonstrated that the EtOAc fraction inhibited NO production and iNOS expression, but it had no effect on iNOS enzyme activity. Additionally, $\mathrm{PGE}_{2}$ production and COX-2 expression were attenuated by the EtOAc fraction in a dose-dependent manner. These results suggest that the EtOAc fraction from $S$. quelpaertensis leaves reduced NO and $\mathrm{PGE}_{2}$ production via transcriptional regulation of iNOS and COX-2 genes. 
Pro-inflammatory cytokines, such as IL-1 $\beta$, IL-6, and TNF- $\alpha$, interact with each other (Pålsson-McDermott \& O'Neill, 2004) and affect LPS-induced macrophage activation during immune responses (Conti et al., 2004). Moreover, IL-1 $\beta$, IL-6, and TNF- $\alpha$ secretion increases in patients with some inflammatory diseases, such as ulcerative colitis and Crohn's disease (Reinecker et al., 1993); these cytokines play an important role in particle-induced inflammation in the lung (Driscoll, 2000; Mansour \& Levitz, 2002; Yucesoy et al., 2002). TNF$\alpha$ is the main mediator of the LPS reaction and is involved in innate immune reactions and chronic inflammatory reactions (Lee et al., 2003). IL-1 $\beta$ is associated with T-cell activation, Bcell maturation, and NK cell activation (Delgado et al., 2003). Therefore, effective regulation of inflammatory mediators is essential (Driscoll, 2000; Hotamisligil, 2008; Hummasti \& Hotamisligil, 2010). In this study, the EtOAc fraction significantly decreased LPS-induced TNF- $\alpha$, IL-1 $\beta$, and IL-6 mRNA levels. This finding suggests that the EtOAc fraction exerts a beneficial health effect by inhibiting the production of many inflammatory mediators.

NF- $\mathrm{kB}$ is an inducible eukaryotic transcription factor that can regulate the expression of numerous genes involved in proliferation, apoptosis, and the immediate-early steps of inflammatory and immune responses (Place et al., 2003). NF-kB activation in response to pro-inflammatory stimuli involves the degradation of inhibitor $\kappa B$ (IкB) by the IкB kinase (IKK) complex. NF- $\mathrm{kB}$ is subsequently released, translocates into the nucleus, and initiates expression of pro-inflammatory mediators such as cytokines, chemokines, adhesion molecules, iNOS, and COX-2 (Baeuerle \& Baltimore, 1996; Hayden \& Ghosh, 2004). Most anti-inflammatory drugs have been shown to suppress the expression of these genes by inhibiting the NF-KB activation pathway (Gilroy et al., 2004). Researchers have recently been working to identify an anti-inflammatory agent to suppress the NF- $\mathrm{kB}$ activation pathway (Le et al., 2009; Reddy \& Reddanna, 2009). Thus, an NF-kB inhibitor may be useful in the development of therapeutic drugs to control the inflammation associated with human diseases in a clinical environment.

The other major extracellular signal transduction pathway stimulated by inflammatory mediators is the MAPK pathway (Guha \& Mackman, 2001). Three major MAPK pathways are a highly conserved family of protein serine/threonine kinases and include the ERK1/2, the c-Jun $\mathrm{NH}_{2}$-terminal kinase (JNK1/2), and the p38 mitogen-activated kinase (p38). These kinases can trigger the nuclear accumulation and activity of various transcription factors, such as NF-kB, ATF2, Elk1, c-fos, and c-jun, which can modulate cytokine and inflammatory mediator expression (Aga et al., 2004; Herlaar \& Brown, 1999).

LPS produces inflammatory mediators by activating the NF-KB and MAPK pathways, and then induces inflammation in macrophages (Aga et al., 2004; Guha \& Mackman, 2001; Zhang \& Ghosh, 2000). On the basis of the inhibitory effect of the EtOAc fraction on the production of inflammatory mediators such as iNOS, COX-2, IL-1 $\beta$, IL-6, and TNF-a, we examined the effect of the EtOAc fraction on NF-kB and MAPK activation in LPS-stimulated RAW 264.7 cells. The EtOAc fraction reduced the transcriptional activities of NF- $\mathrm{kB}$, as well as the delayed phosphorylation of the ERK1/2 in LPS-stimulated RAW 264.7 cells. Taken together, these results suggest that the EtOAc fraction from $S$. quelpaertensis leaves exhibited at least some anti-inflammatory properties by suppressing NF- $\mathrm{kB}$ transcriptional activity and delaying ERK1/2 activation in LPS-stimulated RAW 264.7 cells.

Plants of the genus Sasa are known to biosynthesize various compounds such as triterpenoids, flavonoids, phenylpropanoids, and flavonolignans (Lee et al., 2007; Sultana \& 
Lee, 2009). In previous research, we demonstrated that a hot water extract of S. quelpaertensis leaves exhibited moderate anti-inflammatory activities in LPS-stimulated RAW 264.7 cells (Hwang et al., 2007). An ethanol/water extract of bamboo leaf mainly contains flavones, glycosides, phenolic acids, coumarin lactones, anthraquinones, and amino acids (Lu et al., 2005; Zhang \& Ding, 1996). Thus, the moderate anti-inflammatory activity of the hot water extract may be due to water-soluble phytochemicals. The EtOAc fraction of S. quelpaertensis leaves, which contains mainly lipid-soluble compounds, has exhibited potent antiproliferative effects via inducing apoptosis on human leukemia HL-60 cells (Jang et al., 2008). However, the bioactive compounds contained in the plant have not yet been identified (Sultana \& Lee, 2010). We confirmed that the EtOAc extract contains various compounds, including tricin 7-O- $\beta$-D-glucopyranoside, two phenylpropanoids, $p$-hydroxy benzaldehyde, and $p$-coumaric acid, as we investigated the relationships between various compounds and their antioxidant or anti-inflammatory properties.

\section{Conclusion}

As an initial step to evaluate the beneficial health effects of $S$. quelpaertensis, we investigated the antioxidant activity and anti-inflammatory activity of $S$. quelpaertensis leaf extract. Among the various fractions, the $n$-butanol soluble fraction exhibited the strongest DPPH radical scavenging activity $\left(\mathrm{IC}_{50}=166.4 \mu \mathrm{g} / \mathrm{ml}\right)$. The EtOAc soluble fraction had the strongest inhibitory effect in the NO scavenging activity, superoxide scavenging activity, and xanthine oxidase inhibitory activity assay $\left(\mathrm{IC}_{50}\right.$ values were $259,21.9$, and $32.4 \mu \mathrm{g} / \mathrm{ml}$, respectively). Next, we investigated the anti-inflammatory properties of the EtOAc fraction in LPS-stimulated RAW 274.7 cells. The EtOAc fraction inhibited production of NO, $\mathrm{PGE}_{2}$, iNOS, and COX-2 in a dose-dependent manner. Additionally, pro-inflammatory cytokines, such as IL-1 $\beta$, IL-6, and TNF- $\alpha$, decreased after co-treatment with the EtOAc fraction compared to the LPS-treated group. These results indicate that the EtOAc fraction exhibits anti-inflammatory properties via the inhibition of many inflammatory mediators. Finally, on the basis of the inhibitory effect of the EtOAc fraction on inflammatory mediators, we examined how the EtOAc fraction affected the LPS-induced activation of the NF-KB and MAPK pathways. The EtOAc fraction inhibited the phosphorylation of ERK1/2 and the transactivation of NF- $\mathrm{KB}$, suggesting that the EtOAc fraction suppresses the production of pro-inflammatory mediators via the inhibition of NF-kB transactivation and ERK 1/2 phosprorylation. Taken together, these results indicate that $S$. quelpaertensis leaf has potential for use as an antioxidant and anti-inflammatory agent.

\section{Acknowledgement}

This study was supported by the Grant of Regional Innovation System (B0012292)) of Ministry of Knowledge Economy (MKE), Republic of Korea.

\section{References}

Aga, M., Watters, JJ., Pfeiffer, ZA., Wiepz, GJ., Sommer, JA., \& Bertics, PJ. (2004). Evidence for nucleotide receptor modulation of cross talk between MAP kinase and NFkappa B signaling pathways in murine RAW 264.7 macrophages. American Journal 
of Physiology - Cell Physiology, Vol. 286, No. 4, (April, 2004), pp. (C923-930), 03636143

Bae, K. (2000). The Medicinal plants of Korea, Kyo-Hak Publishing Company, 8909056584, Seoul, Republic of Korea

Baeuerle, PA., \& Baltimore, D. (1996). NF-kappa B: ten years after. Cell, Vol. 87, No. 1, (October, 1996), pp. (13-20), 0092-8674

Bennett, A., Carroll, MA., Stamford, IF., \& Williams, F. (1982). Prostaglandins and human lung carcinomas. British journal of cancer, Vol. 46, No. 6, (December, 1982), pp. (888893), 0007-0920

Bennett, A., Carter, L., \& Stamford, IF. (1980) Prostaglandin-like material extracted from squamous cacinomas of the head and neck. British journal of cancer, Vol. 41, No. 2, (February, 1980), pp. (204-208), 007-0920

Bennett, A., Charlier, EM., McDonald, AM., Simpson, JS., Stamford, IF., \& Zebro, T. (1977). Prostaglandins and breast cancer. The Lancet, Vol. 310, No. 8039, (September, 1977), pp. (624-626), 0099-5355

Bredt, DS., \& Snyder, SH. (1990). Isolation of nitric oxide synthetase, a calmodulin-requiring enzyme. Proceedings of the National Academy of Sciences of the United States of America, Vol. 87, No. 2, (January, 1990), pp. (682-685), 0027-8424

Calfee-Mason, KG., Spear, BT., \& Glauert, HP. (2002). Vitamin E inhibits hepatic NF-kappaB activation in rats administered the hepatic tumor promoter, phenobarbital. Journal of Nutrition, Vol. 132, No. 10, (October, 2002), pp (3178-3185), 0022-3166

Choi, YJ., Lim, HS., Choi, JS., Shin, SY., Bae, JY., Kang, SQ., Kang, IJ., \& Kang, YH. (2008). Blockage of chronic high glucose-induced endothelial apoptosis by Sasa borealis bamboo extract. Experimental Biology and Medicine, Vol. 233, No. 5, (May, 2008), pp. (580-591), 1535-3702

Conti, B., Tabarean, I., Andrei, C., \& Bartfai, T. (2004). Cytokines and fever. Frontiers in bioscience, Vol. 9, No 1, (May, 2004), pp. (1433-1449), 1093-9946

Delanty, N., \& Dichter, MA. (1998). Oxidative injury in the nervous system. Acta Neurologica Scandinavica, Vol. 98, No. 3, (September, 1998), pp. (145-153), 0001-6314

Delgado, AV., McManus, AT., \& Chambers, JP. (2003). Production of tumor necrosis factoralpha, interleukin 1-beta, interleukin 2 and interleukin 6 by rat leukocyte subpopulations after exposure to substance. Neuropeptides, Vol. 37, No. 6, (December, 2003), pp. (355-361), 0143-4179

Driscoll, KE. (2000). TNF-alpha and MIP-2: role in particle-induced inflammation and regulation by oxidative stress. Toxicology Letters, Vol. 112-113, (March, 2000), pp. (177-183), 0378-4274

Feelisch, M., \& Stamler, JS. (1st Ed.). (1996). Methods in nitric oxide research, John Wiley \& Sons, 0471955248, Chichester, England

Gallin, JI., \& Snyderman, R. (3rd Ed.). (1999). Inflammation: Basic principles and Clinical Correlates, Lippincott Williams \& Wilkins, 9780397517596, Pennsylvania, United States of America

Gilroy, DW., Lawrence, T., Perretti, M., \& Rossi, AG. (2004). Inflammatory Resolution: new opportunities for drug discovery. Nature Reviews Drug Discovery, Vol. 3, No. 5, (May 2004), pp. (401-416), 1474-1776

Gold, ME., Wood, KS., Byrns, RE., Fukuto, J., \& Ignarro, LJ. (1990). NG-methyl-L-arginine causes endothelium-dependent contraction and inhibition of cyclic GMP formation 
in artery and vein. Proceedings of the National Academy of Sciences of the United States of America, Vol. 87, No. 1, (June, 1990), pp. (4430-4434), 0027-8424

Green, LC., Wagner, DA., Glogowski, J., Skipper, PL., Wishnok, JS., \& Tannenbaum, SR. (1982). Analysis of nitrate, nitrite, and $\left[{ }^{15} \mathrm{~N}\right]$ nitrate in biological fluids. Analytical biochemistry, Vol. 126, No. 1, (October, 1982), pp. (131-138), 0003-2697

Guha, M., \& Mackman, N. (2001). LPS induction of gene expression in human monocytes. Cellular Signalling, Vol. 13, No. 2, (February, 2001), pp. (85-94), 0898-6568

Hasegawa, T., Tanaka, A., Hosoda, A., Takano, F., \& Ohta, T. (2008). Antioxidant C-glycosyl flavones from the leaves of Sasa kurilensis var. gigantea. Phytochemistry, Vol. 69, No. 6, (April, 2008), pp. (1419-1424), 0031-9422

Hayden, MS., \& Ghosh, S. (2004). Signaling to NF-kappaB. Genes \& Development, Vol. 18, No. 18, (September, 2004), pp. (2195-2224), 0890-9369

Herlaar, E., \& Brown, Z. (1999). p38 MAPK signalling cascades in inflammatory disease. Molecular Medicine Today, Vol. 5, No. 10, (October, 1999), pp. (439-447), 1357-4310

Hotamisligil, GS. (2008). Inflammation and endoplasmic reticulum stress in obesity and diabetes. International journal of obesity (Lond), Vol. 32 (Suppl 7), (December, 2008), pp. (S52-S54), 0307-0565

Hummasti, S., \& Hotamisligil, GS. (2010). Endoplasmic reticulum stress and inflammation in obesity and diabetes. Circulation Research, Vol. 107, No. 5, (September, 2010), pp. (579-591), 0009-7330

Hwang, JH., Choi, SY., Ko, HC., Jang, MG., Jin, YJ., Kang, SI., Park, JG., Chung, WS., \& Kim, SJ. (2007). Anti-inflammatory Effect of the Hot Water Extract from Sasa quelpaertensis Leaves. Food Science and Biotechnology, Vol. 16, No. 5, pp. (728-733), 1226-7708

Jang, MG., Park, SY., Lee, SR., Choi, SY., Hwang, JH., Ko, HC., Park, JG., Chung, WS., \& Kim, SJ. (2008). Sasa quelpaertensis leaf extracts induce apoptosis in human leukemia HL-60 cells. Food Science and Biotechnology, Vol. 17, No. 1, pp. (188-190), 1226-7708

Jeong, YH., Chung, SY., Han, AR., Sung, MK., Jang, DS., Lee, J., Kwon, Y., Lee, HJ. \& Seo, EK. (2007). P-glycoprotein inhibitory activity of two phenolic compound, (-)syrigaresinol and tricin from Sasa borealis. Chemistry and Biodiversity, Vol. 4, No. 1, pp. (12-16), 1612-1872

Jensen, GS., Wu, X., Patterson, KM., Barnes, J., Carter, SG., Scherwitz, L., Beaman, R., Endres, JR., \& Schauss, AG. (2008). In vitro and in vivo antioxidant and antiinflammatory capacities of an antioxidant-rich fruit and berry juice blend. Results of a pilot and randomized, double-blinded, placebo-controlled, crossover study. Journal of Agricultural and Food Chemistry, Vol. 56, No. 18, (September, 2008), pp. (8326-8333), 0021-8561

Kurokawa, T., Itagaki, S., Yamaji, T., Nakata, C., Nodo, T., Hirano, T. \& Iseki, K. (2006). Antioxidant activity of a novel extract from bamboo grass (AHSS) against ischemiareperfusion injury in rat small intestine. Biological \& Pharmaceutical Bulletin, Vol.29, No.11, (November, 2006), pp. (2301-2303), 0918-6158

Lee, AK., Sung, SH., Kim, YC., \& Kim, SG. (2003). Inhibition of lipopolysaccharide-inducible nitric oxide synthase, TNF-a and COX-2 expression by sauchinone effect in I-kBa phosphorylation, C/EBP and AP-1 avtivation. British journal of pharmacology, Vol. 139, No. 1, (May, 2003), pp. (11-20), 0007-1188 
Lee, J., Jeong, YH., Jang, DS., \& Seo, EK. (2007). Three terpenes and one phenolic compounds from Sasa borealis. Journal of Applied Biological Chemistry, Vol. 50, No. 1, (March, 2007), pp. (13-16), 1976-0442

Lee, TY., Lee, KC., Chen, SY., \& Chang, HH. (2009). 6-Gingerol inhibits ROS and iNOS through the suppression of PKC-alpha and NF-kappaB pathways in lipopolysaccharide-stimulated mouse macrophages. Biochemical and Biophysical Research Communications, Vol. 382, No. 1, (April, 2009), pp. (134-139), 0006-291X

Lu, B., Wu, X., Tie, X., Zhang, Y., \& Zhang, Y. (2005). Toxicology and safety of anti-oxidant of bamboo leaves. Part 1: Acute and subchronic toxicity studies on anti-oxidant of bamboo leaves. Food and Chemical Toxicology, Vol. 43, No. 5, (May, 2005), pp. (783792), 0278-6915

Mansour, MK., \& Levitz, SM. (2002). Interactions of fungi with phagocytes. Current Opinion in Microbiology, Vol. 5, No. 4, (August, 2002), pp. (359-365), 1369-5274

Martínez, JA. (2006). Mitochondrial oxidative stress and inflammation: an slalom to obesity and insulin resistance. Journal of physiology and biochemistry, Vol. 62, No. 4, (December, 2006), pp. (303-306), 1138-7548

Muñoz, E., Blázquez, MV., Ortiz, C., Gomez-Díaz, C., \& Navas, P. (1997). Role of ascorbate in the activation of NF-kappaB by tumour necrosis factor-alpha in T-cells. Biochemical Journal, Vol. 325, No. Pt 1, (July 1997), pp. (23-28), 0264-6021

Nakajima, Y., Yun, YS., \& Kunugi, A. (2003). Six new flavonolignans from Sasa veitchii (Carr.) Rehder. Tetrahedron, Vol. 59, No. 40, (September, 2003), pp. (8011-8015), 0040-4020

Okabe, S., Takeuchi, K., Takagi, K., \& Shibata, M. (1975). Stimulatory effect of the water extract of bamboo grass (Folin solution) on gastric acid secretion in pylorus-ligated rats. Japanese Journal of Pharmacology, Vol. 25, No. 5, (October, 1975), pp. (608-609), 0021-5198

Palmer, RM., Ferrige, AG., \& Moncada, S. (1987). Nitric oxide release accounts for the biological activity of endothelium-derived relaxing factor. Nature, Vol. 327, No. 6122, (June, 1987), pp. (524-526), 0028-0836

Pålsson-McDermott, EM., \& O'Neill, LA. (2004). Signal transduction by the lipopolysaccharide receptor, Toll-like receptor-4. Immunology, Vol. 113, No. 2, (October, 2004), pp. (153-162), 0019-2805

Park, HS., Lim, JH., Kim, HJ., Choi, HJ., \& Lee, IS. (2007). Antioxidant flavones glycosides from the leaves of Sasa borealis. Archives of Pharmacal Research, Vol. 30, No. 2, (February, 2007), pp. (161-166), 0253-6269

Place, RF., Haspeslagh, D., \& Giardina, C. (2003). Induced stabilization of IkappaBalpha can facilitate its re-synthesis and prevent sequential degradation. Journal of Cellular Physiology, Vol. 195, No. 3, (June, 2003), pp. (470-478), 0021-9541

Posadas, I., Terencio, MC., Guillén, I., Ferrándiz, ML., Coloma, J., Payá, M., \& Alcaraz, MJ. (2000). Co-regulation between cyclo-oxygenase-2 and inducible nitric oxide synthase expression in the time-course of murine inflammation. NaunynSchmiedeberg's Archives of Pharmacology, Vol. 361, No. 1, (January, 2000), pp. (98106), 0028-1298

Puig, JG., Mateos, FA., \& Diaz, VD. (1989). Inhibition of xanthine oxidase by allopurinol: a therapeutic option for ischaemia induced pathological processes?. Annals of the rheumatic diseases, Vol. 48, No. 11, (November, 1989), pp. (883-888), 0003-4967 
Raidaru, G., Ilomets, T., Mottus, A. \& Maser, M. (1997). Isolation of polysaccharides with antitumor activity from Sasa kurilensis(Fr. et Sar.). Experimental Oncology, Vol. 20, No. 4, pp. (34-39), 1812-9269

Reddy, DB., \& Reddanna, P. (2009). Chebulagic acid (CA) attenuates LPS-induced inflammation by suppressing NF-kappaB and MAPK activation in RAW 264.7 macrophages. Biochemical and Biophysical Research Communications, Vol. 381, No. 1, (March, 2009), pp. (112-117), 0006-291X

Reinecker, HC., Steffen, M., Witthoeft, T., Pflueger, I., Schreiber, S., MacDermott, RP., \& Raedler, A. (1993). Enhanced secretion of tumour necrosis factor-alpha, IL-6, and IL-1 beta by isolated lamina propria mononuclear cells from patients with ulcerative colitis and Crohn's disease. Clinical \& Experimental Immunology, Vol. 4, No. 1, (October, 1993), pp. (174-181), 0009-9104

Ren, M., Reilly, RT., \& Sacchi, N. (2004). Sasa health exerts a protective effects on Her2/NeuN mammary tumorigenesis. Anticancer Research, Vol. 24, No. 5A, (September-October, 2004), pp. (2879-2884), 0250-7005

Rigas, B., Goldman, IS., \& Levine, L. (1993). Altered eicosanoid levels in human colon cancer. The Journal of laboratory and clinical medicine, Vol. 122, No. 5, (November, 1993), pp. ( 518-523), 0022-2143

Salvemini, D., Manning, PT., Zweifel, BS., Seibert, K., Connor, J., Currie, MG., Needleman, P., \& Masferrer, JL. (1995). Dual inhibition of nitric oxide and prostaglandin production contributes to the antiinflammatory properties of nitric oxide synthase inhibitors. The Journal of clinical investigation, Vol. 96, No. 1, (July, 1995), pp. (301308), 0021-9738

Seki, T., Morimura, S., Ohba, H., Tang, Y., Shigematsu, T., Maeda, H., \& Kida, K. (2008). Immunostimulation-mediated antitumor activity by preconditioning with riceshochu distillation residue against implanted tumor in mice. Nutrition $\mathcal{E}$ Cancer, Vol. 60, No. 6, (2008), pp. (776-783), 0163-5581

Shibata, M., Yamatake, M., Sakamoto, M., Kanamori, K., \& Takagi, K. (1975). Phamacological studies on bamboo grass (1). Acute toxicity and anti-inflammatory and antiulcerogenic activities of water-soluble fraction(Folin) extracted from Sasa albomarginata Makino et Shibata. Nippon Yakurigaku Zasshi, Vol. 71, No. 5, (July, 1975), pp. (481-485), 0015-5691

Shibata, M., Fujii, M., \& Yamaguchi, R. (1979). Pharmacological studies on bamboo grass. IV. Toxicological and pharmacological effects of the extract (FIII) obtained from Sasa albomarginata Makino et Shibata (author's transl). Nippon Yakurigaku Zasshi, Vol. 99, No. 6, (June, 1979), pp. (663-668), 0015-5691

Sood, S., Arora, B., Bansal, S., Muthuraman, A., Gill, NS., Arora, R., Bali, M., \& Sharma, PD. (2009). Antioxidant, anti-inflammatory and analgesic potential of the Citrus decumana L. peel extract. Inflammopharmacology, Vol. 17, No. 5, (October, 2009), pp. (267-274), 0925-4692

Sultana, N., \& Lee, NH. (2010). A new alkene glycoside from the leaves of Sasa quelpaertensis Nakai. Bulletin of the Korean Chemical Society, Vol. 31, No. 4, (April, 2010), pp. (1088-1090), 0253-2964

Sultana, N., \& Lee, NH. (2009). New phenylpropanoids from Sasa quelpaertensis Nakai with Tyrosinase inhibition acitivities. Bulletin of the Korean Chemical Society, Vol. 30, No. 8, (August, 2009), pp. (1729-1732), 0253-2964 
Suzuki, S., Saito, T., Uchiyama, M., \& Akiya, S. (1968). Studies on the anti-tumor activity of polysaccharides. I. Isolation of hemicelluloses from Yakushima-bamboo and their growth inhibitory activity against sarcoma-180 solid tumor. Chemical $\mathcal{E}$ Pharmaceutical Bulletin, Vol. 16, No. 10, (October, 1968), pp. (2032-2039), 0918-6158

Tateyama, C., Ohta, M. \& Uchiyama, T. (1997). Free radical scavenging activities of flower petals extracts. Journal of the Japanese Society of Food Science and Technology, Vol. 44, No. 9, (June, 1998), pp. (640-646), 1341-027X

Tracey, KJ. (2002). The inflammatory reflex. Nature, Vol. 420, No. 6917, (December, 2002), pp. (853-859), 0028-0836

Tsatsanis, C., Androulidaki, A., Venihaki, M., \& Margioris, AN. (2006). Signalling networks regulating cyclooxygenase-2. The International Journal of Biochemistry \& Cell Biology, Vol. 38, No. 10, (April, 2006), pp. (1654-1661), 1357-2725

Tsunoda, S., Yamamoto, K., Skamoto, S., Inoue, H., \& Nagasawa, H. (1998). Effects of Sasa Health, extract of bamboo grass leaves, on spontaneous mammary tumourigenesis in SHN mice. Anticancer Research, Vol, 18, No. 1A, (January-February, 1998), pp. (153-158), 0250-7005

Valko, M., Leibfritz, D., Moncol, J., Cronin, MT., Mazur, M., \& Telser, J. (2007). Free radicals and antioxidants in normal physiological functions and human disease. The International Journal of Biochemistry \& Cell Biology, Vol. 39, No. 1, (August, 2006), pp. (44-84), 1357-2725

Victor, VM., \& Rocha, M. (2007). Targeting antioxidants to mitochondria: a potential new therapeutic strategy for cardiovascular diseases. Current Pharmaceutical Design, Vol. 13, No. 8, (March, 2007), pp. (845-863), 1381-6128

Winrow, VR., Winyard, PG., Morris, CJ., \& Blake, DR. (1993). Free radicals in inflammation: second messengers and mediators of tissue destruction. British Medical Bulletin, Vol. 49, No. 3, (July, 1993), pp. (506-522), 0007-1420

Yang, JH., Lim, HS., \& Heo, YR. (2010). Sasa borealis leaves extract improves insulin resistance by modulating inflammatory cytokine secretion in high fat diet-induced obese C57/BL6J mice. Nutrition Research and Practice, Vol. 4, No. 2, (April, 2010), pp. (99-105), 1976-1457

Yamafuji, K., \& Murakami, H. (1968). Antitumor potency of lignin and pyrocatecol and their action on deoxyribonucleic acid. Enzymologia, Vol. 35, No. 3, (September, 1968), pp. (139-153), 0013-9424

Yucesoy, B., Vallyathan, V., Landsittel, DP., Simeonova, P., \& Luster, MI. (2002). Cytokine polymorphisms in silicosis and other pneumoconioses. Molecular and Cellular Biochemistry, Vol. 234-235, No. 1-2, (May-June, 2002), pp. (219-224), 0300-8177

Zhang, G., \& Ghosh, S. (2000). Molecular mechanisms of NF-kappaB activation induced by bacterial lipopolysaccharide through Toll-like receptors. Journal of Endotoxin Research, Vol. 6, No. 6, (2000), pp. (453-457), 0968-0519

Zhang, Y., \& Ding, XL. (1996). Studies on anti-oxidative fraction in bamboo leaves and its capacity to scavenge active oxygen redicals. Journal of Bamboo Research, Vol. 15, No. 3, (1996), pp. (17-24), 1000-6567 


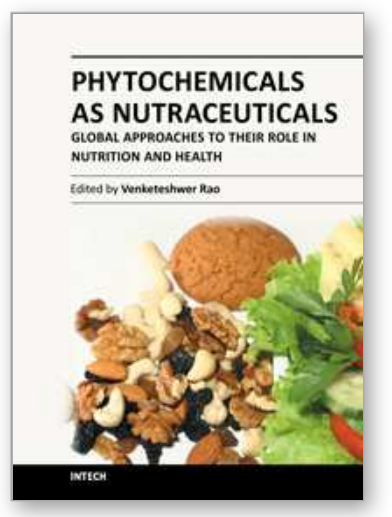

\author{
Phytochemicals as Nutraceuticals - Global Approaches to Their \\ Role in Nutrition and Health \\ Edited by Dr Venketeshwer Rao
}

ISBN 978-953-51-0203-8

Hard cover, 278 pages

Publisher InTech

Published online 23, March, 2012

Published in print edition March, 2012

Phytochemicals are biologically active compounds present in plants used for food and medicine. A great deal of interest has been generated recently in the isolation, characterization and biological activity of these phytochemicals. This book is in response to the need for more current and global scope of phytochemicals. It contains chapters written by internationally recognized authors. The topics covered in the book range from their occurrence, chemical and physical characteristics, analytical procedures, biological activity, safety and industrial applications. The book has been planned to meet the needs of the researchers, health professionals, government regulatory agencies and industries. This book will serve as a standard reference book in this important and fast growing area of phytochemicals, human nutrition and health.

\title{
How to reference
}

In order to correctly reference this scholarly work, feel free to copy and paste the following:

Se-Jae Kim, Joon-Ho Hwang, Hye-Sun Shin, Mi-Gyeong Jang, Hee-Chul Ko and Seong-II Kang (2012). Antioxidant and Anti-Inflammatory Activities of Sasa quelpaertensis Leaf Extracts, Phytochemicals as Nutraceuticals - Global Approaches to Their Role in Nutrition and Health, Dr Venketeshwer Rao (Ed.), ISBN: 978-953-51-0203-8, InTech, Available from: http://www.intechopen.com/books/phytochemicals-asnutraceuticals-global-approaches-to-their-role-in-nutrition-and-health/antioxidant-and-anti-inflammatoryactivities-of-sasa-quelpaertensis-extracts

\section{INTECH}

open science | open minds

\section{InTech Europe}

University Campus STeP Ri

Slavka Krautzeka 83/A

51000 Rijeka, Croatia

Phone: +385 (51) 770447

Fax: +385 (51) 686166

www.intechopen.com

\section{InTech China}

Unit 405, Office Block, Hotel Equatorial Shanghai

No.65, Yan An Road (West), Shanghai, 200040, China

中国上海市延安西路65号上海国际贵都大饭店办公楼 405 单元

Phone: +86-21-62489820

Fax: $+86-21-62489821$ 
(C) 2012 The Author(s). Licensee IntechOpen. This is an open access article distributed under the terms of the Creative Commons Attribution 3.0 License, which permits unrestricted use, distribution, and reproduction in any medium, provided the original work is properly cited. 